\title{
Soil Fertility Status of Major Nutrients, Micronutrients and Mapping in Nicchapura-2 Micro Watershed of Davanagere District, Karnataka, India
}

\author{
N.R. Krishna, P. Chandravamshi and L.B. Ashok ${ }^{*}$ \\ Department of Soil Science and Agricultural Chemistry, University of Agricultural and \\ Horticultural Sciences, Shivamogga- 577204, India \\ *Corresponding author
}

\section{A B S T R A C T}

\begin{tabular}{|l|}
\hline Ke y w o r d s \\
KSRSAC- \\
Karnataka State \\
Remote Sensing \\
and Application \\
Centre, Toposheet, \\
Codastral maps and \\
grids, GIS.
\end{tabular}

Keywords

KSRSAC-

Centre, Toposheet,

Codastral maps and rids, GIS

\section{Introduction}

Role of balanced plant nutrition is well established for sustainable agricultural production. Presen agricultural systems are explotive of nutrients through intensive tillage, monocroping, use of high yielding varieties, imbalanced use of nutrients coupled with limited use of organic manures, less recycling and burning of crop recidues, soil erosion. Balanced use of organics, fertilizers and biofertilizers plays an important role to maintain soil fertility in long run. The availability of macro and micronutrients to plants as influenced by several soil characterstics. Similarly different cropping systems are suitable for different soil groups as regards to production and productivity, for understanding the reasons of deficiancy of available nutrients in soils with available macro and micronutrients was needed. Also detailes study on status of macro and micronutrients in both black and red soils of Nicchapura-2 microwatershed.this region has both black and red soils. Hence present investigation was undertaken to study the Soil fertility status of major nutrients, micronutrients and mapping in Nicchapura-2 micro watershed of Davanagere district, Karnataka. 


\section{Materials and Methods}

The study area is a Nichhapura-2 micro watershed, covering an area of 630.16 ha. The district lies in the center of Karnataka between the latitudes $13^{\circ} 5^{\prime}$ and $14^{\circ} 50^{\prime} \mathrm{N}$ and between the longitudes $75^{\circ} 30^{\prime}$ and $76^{\circ} 30^{\prime} \mathrm{E}$. The average rainfall in study area is $613 \mathrm{~mm}$. The survey of India toposheet (57 A/6) was used to prepare base maps covering village of Nicchapura-2, this micro-watershed. The cadastral map having parcel boundaries and survey members are produced from KSRSAC Bangalore. The boundary of the micro watershed was obtained from the watershed Atlas prepared by KSRSAC. The survey of India toposheet (57A/6) with 1:50.000 scales was also used along with satellite imagery, Google earth maps for updating the base map.A surface soil sample from 0 to $20 \mathrm{~cm}$ was collected at $250 \mathrm{~m} \times 250 \mathrm{~m}$ grid samples in the study area. A total of 103 samples were collected from the fixed grid points. The processed samples were analyzed for physicochemical properties and available nutrients using standard procedure (Table 1).

\section{Soil fertility maps}

Using the field survey, and laboratory analysis results, the soil heterogeneity units were determined using remote sensing and GIS by following the guidelines of Soil Survey Staff (1999).A dbf file consisting of data for $\mathrm{X}$ and $\mathrm{Y}$ co-ordinates in respect of sampling site location was created. A shape file (Vector data) showing the outline of Nicchapura-2 village. The dbf file was opened in the project window and in $X$-field, $X$ coordinates were selected and in Y-field, Ycoordinates were selected. The $\mathrm{Z}$ field was used for different nutrients. The nichhapura-2 village shape file was also opened and from the surface menu of Arc view spatial analyst "Interpolate grid option" was selected. On the output "grid specification dialogue", output grid extend chosen was same as Nicchapura-2 village shape and the interpolation method employed was spline. Then map was reclassified based on ratings of respective nutrients.

\section{Results and Discussion}

The soil $\mathrm{pH}$ of the micro watershed ranged from slightly acidic to alkaline (Table 2) of Nicchapura-2 micro watershed of Harappanahalli taluk, Davanagere district. Soil reaction was neutral to alkaline in black soils (range 7.2 to 8.7 ) while slightly acidic to slightly alkaline in red soils (range 6.2 to 8.1 ). The variation in soil $\mathrm{pH}$ was related to the parent material, and topography. Relatively higher $\mathrm{pH}$ value in black soils was due to the accumulation of the high amounts of exchangeable bases in solum as they are poorly drained. The relatively low $\mathrm{pH}$ in red soils was mainly due to iron hydroxide species which contributed for higher for higher $\mathrm{H}^{+}$concentration (Dasog and Patil, 2011). On area basis, 425 ha $(67.43 \%)$ was moderately alkaline, 182 ha $(28.85 \%)$ slightly alkaline 12 ha (2\%) neutral and 10 ha $(1.70 \%)$ strongly alkaline nature in Microwatershed area (Fig. 1).

The electrical conductivity values were very low $\left(0.11\right.$ to $\left.0.84 \mathrm{dS} \mathrm{m}^{-1}\right)$ indicating that the soils of selected micro watershed were non saline in nature (Table 2). This may be due to undulating nature of the terrain coupled with fairly good drainage conditions, which favored the removal of released bases by the percolating drainage water. In all the soil samples electrical conductivity was lesser than $4 \mathrm{dS} \mathrm{m}^{-1}$ which was below the safe limit. This indicates non-saline in nature of the soils. This may be due to undulating nature of the terrain coupled with fairly good drainage conditions, which favored the removal of released bases by the percolating drainage water (Shivaprasad et al., 1998). On area 
basis, total of 630.16 ha $(100 \%)$ are nonsaline in nature (Fig. 1).

The soil organic carbon content (SOC) was low in majority of soil samples and it ranged from accounting 100 per cent in microwatershed area. Patil et al., (2011) reported that soils of semi-arid type of climate with temperature prevailing in the area resulted in low to medium organic carbon content. The black soils were relatively higher soil organic carbon content compared to red soils (Table 2 and Fig. 1). The low organic matter content in the soils was attributed to the prevalence of tropical condition, where the degradation of organic matter occurs at a faster rate coupled with low vegetation cover, thereby leaving less organic carbon in the soils (Sireesha and Naidu, 2013). The organic matter degradation and removal taken place at faster rate coupled with low vegetation cover thereby leaving less changes of accumulation of organic matter in the soil. According to Rao et al., (2008) higher clay content in black soil was responsible for higher organic carbon content.

\section{Primary nutrient status}

The available nitrogen status of the micro watershed ranged from low to medium (156 to $\left.229 \mathrm{~kg} \mathrm{ha}^{-1}\right)$. In general, the black soils (156 to $236 \mathrm{~kg} \mathrm{ha}^{-1}$ ) contained higher nitrogen than red soils (135 to $229 \mathrm{~kg} \mathrm{ha}^{-1}$ ) and the main reason being low organic matter content, Low rainfall and low vegetation were reported to cause faster degradation and removal of organic matter leading to nitrogen deficiency (Ashok, 2001).

The variation in $\mathrm{N}$ content may be related to soil management, application of FYM and fertilizer to previous crop etc. The semi-arid climate, low organic carbon status might have been resulted in low $\mathrm{N}$ content. On the area basis majority of soils are low in available nitrogen 630.16 ha (Fig. 2).
The available phosphorus status in micro watershed area was ranged from low to medium (10 to $\left.34 \mathrm{~kg} \mathrm{ha}{ }^{-1}\right)$. Available phosphorus content in black soil ranged from 22 to $34 \mathrm{~kg} \mathrm{ha}^{-1}$ and red soils ranged from 10 to $31 \mathrm{~kg} \mathrm{ha}^{-1}$. In general, black soils are higher phosphorus content than red soils. This might be due to variation in soil properties like clay content, CEC and $\mathrm{P}$ fixation capacity. In addition to this, the farmers are using only DAP as the source of nutrients in large quantity. The red soils show low values of available (Table 2) phosphorus, which may be due to low CEC, clay content and acidic soil reaction of $<6.5$ About 619 ha which accounted for 98.28 per cent of the microwatershed area was medium and 11 ha (1.71 $\%)$ are low in available phosphorus status (Fig. 2).

The available potassium content in major portion of the study area was under medium to high category. In Black soils (236 to 415 $\mathrm{kg} \mathrm{ha}^{-1}$ ) shows higher values than red soils (130 to $402 \mathrm{~kg} \mathrm{ha}^{-1}$ ) due to predominance of $\mathrm{K}$ rich micaceous and feldspar minerals in parent (Pal, 1985 and Ravikumar, 2004). The higher content of potassium might be due to the predominance of potash rich micaceous and feldspar minerals in parent rocks (Dasog and Patil, 2011 and Pulakeshi et al., 2014). In this micro-watershed about 416 ha and 214 ha area occupying 65.95 per cent and 34.04 per cent (Fig. 2) were medium and high available potassium respectively.

\section{Secondary nutrient status}

The exchangeable calcium and magnesium content of micro-watershed area ranged from

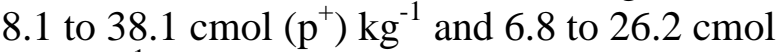
$\left(\mathrm{p}^{+}\right) \mathrm{kg}^{-1}$ respectively (Table 2 and Figure 3 ) In black soils exchangeable calcium and magnesium content ranged from 15.3 to 38.1 cmol $\left(\mathrm{p}^{+}\right) \mathrm{kg}^{-1}$ and 6.8 to $26.2 \mathrm{cmol}\left(\mathrm{p}^{+}\right) \mathrm{kg}^{-1}$, respectively. 
Fig.1 pH, EC, available N and OC status of Nicchapura-2 micro-watershed
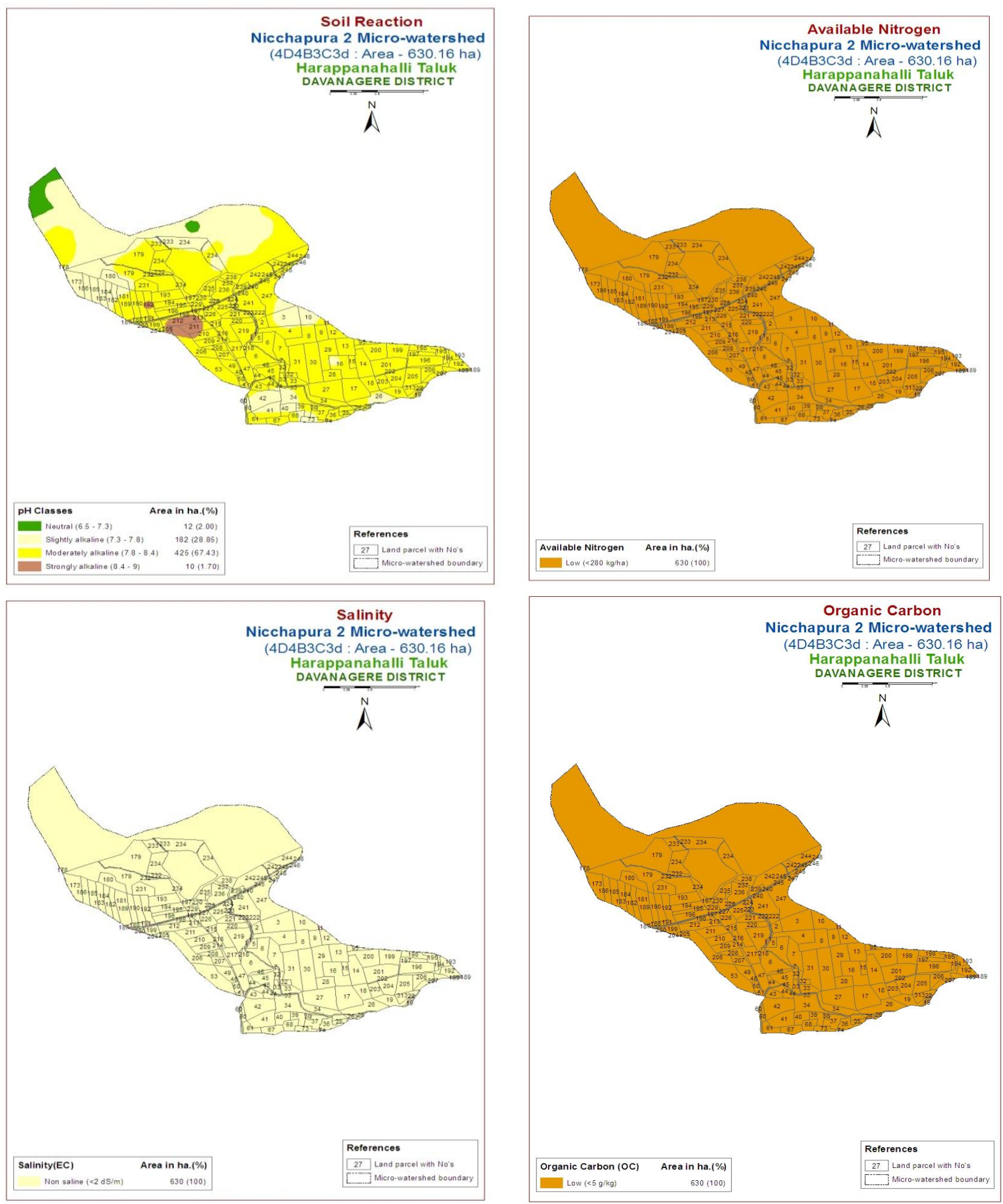
Fig.2 Available $\mathrm{P}_{2} \mathrm{O}_{5}, \mathrm{~K}_{2} \mathrm{O}$ and exchangeable $\mathrm{Ca}$ and $\mathrm{Mg}$ status of Nicchapura-2 micro watershed
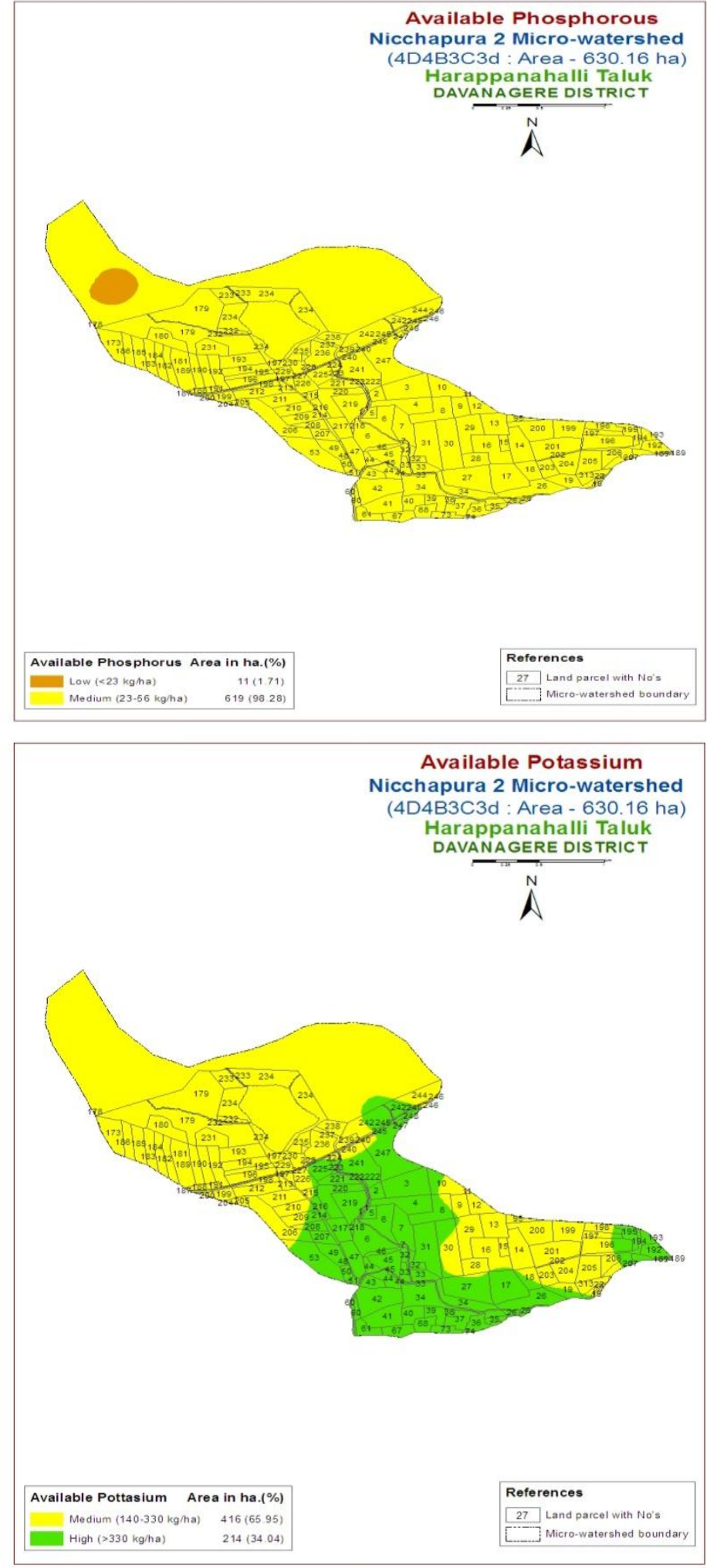

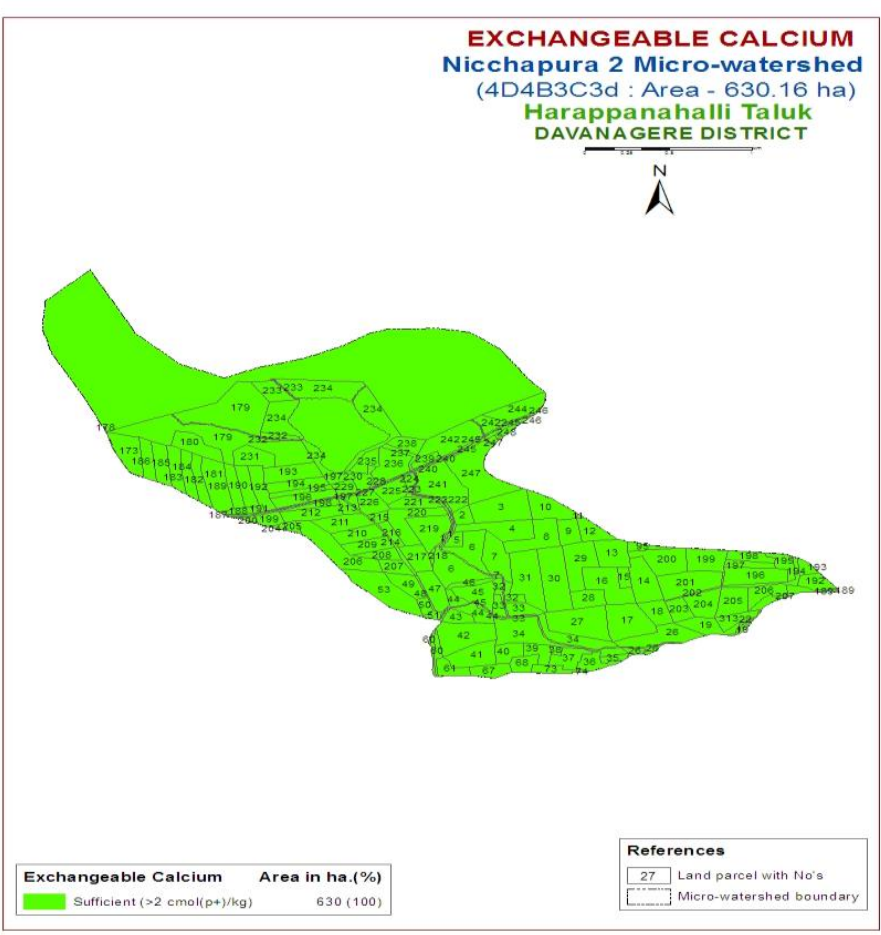

Exchangeable Magnesium Nicchapura 2 Micro-watershed (4D4B3C3d : Area - 630.16 ha) Harappanahalli Taluk DAVANAGERE DISTRICT
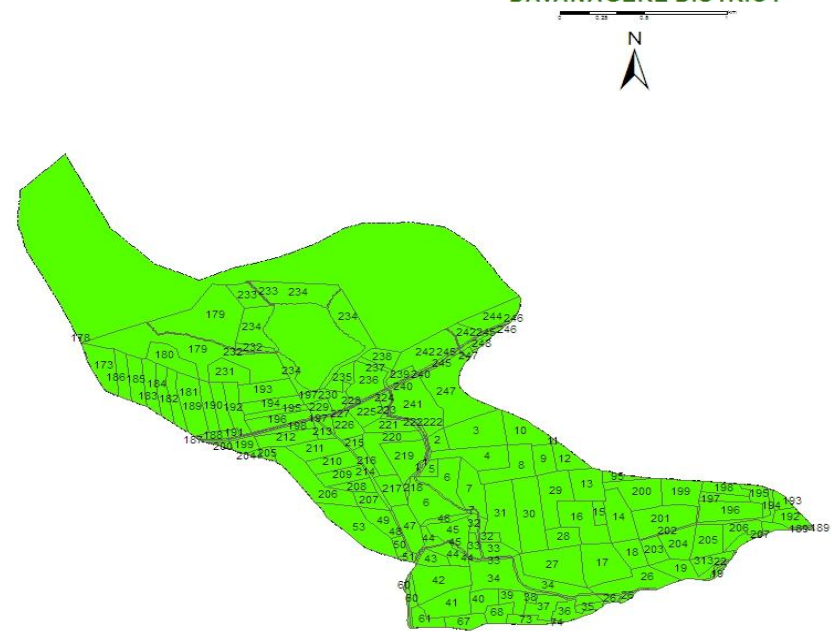

Exchangeable Magnesium Area in ha. $(\%)$ References

27 Land parcel with No's L-- Micro-watershed bound ary 
Fig.3 Available S, Fe, Mn, Cu and Zn status of Nicchapura-2 micro-watershed
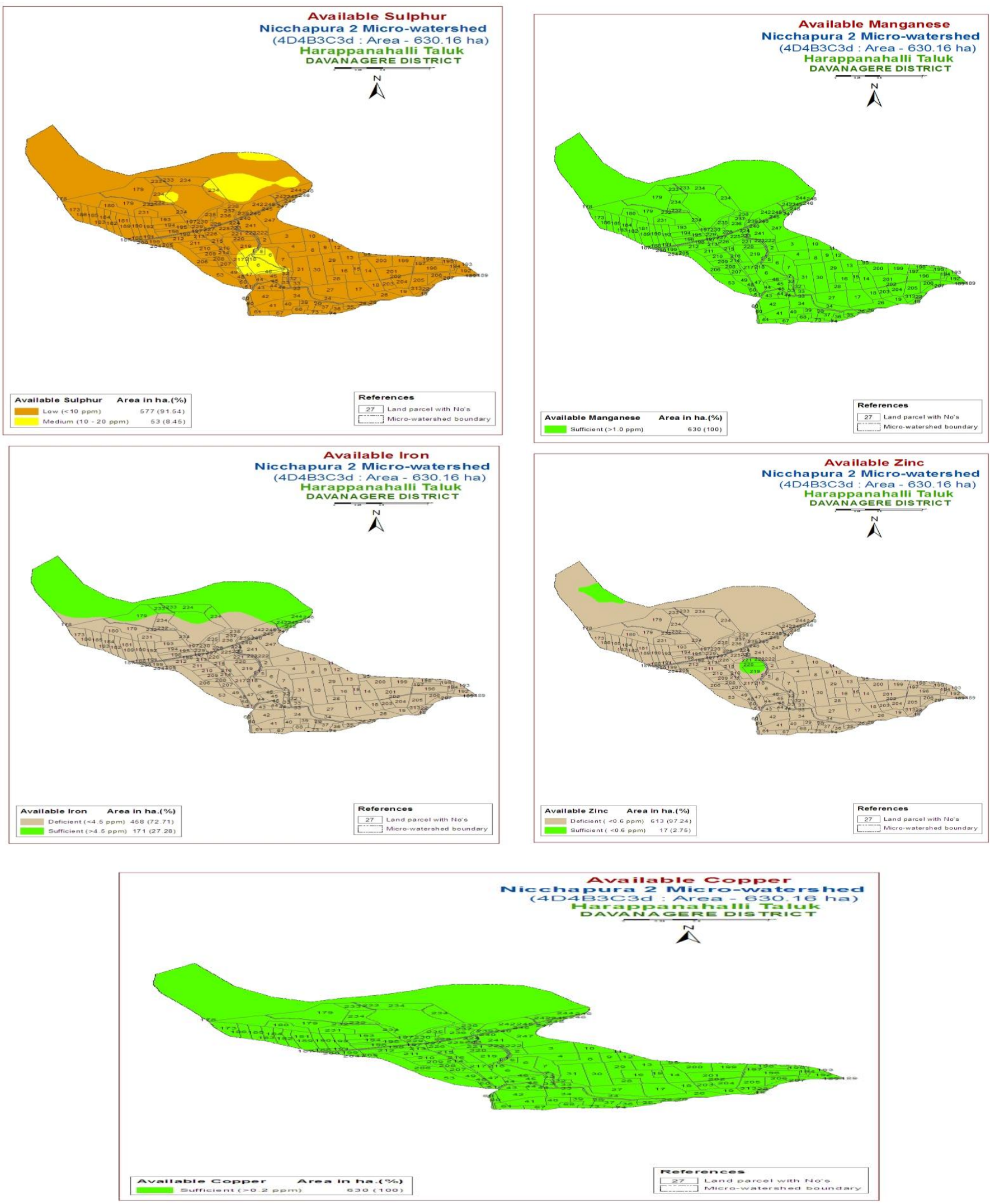
Table.1 Methods adopted for estimation of properties

\begin{tabular}{|l|l|}
\hline Soil parameters & Methods adopted \\
\hline Soil reaction & Jackson,1973 \\
\hline Electrical conductivity & Jackson,1973 \\
\hline Organic carbon & Walkey and Black,1934 \\
\hline Available nitrogen & Subbaiah and Asija,1956 \\
\hline Available phosphorus & Jackson,1973 \\
\hline Available potassium & Jackson,1973 \\
\hline Exchangeable calcium and Magnesium & Jackson,1973 \\
\hline Available sulphur & Black (1965) \\
\hline DTPA extractable micronutrients & Lindsay and Norvell (1978). \\
\hline
\end{tabular}

Table.2 Physico-chemical properties and major nutrient status in Nicchapura-2 watershed

\begin{tabular}{|l|c|l|l|l|}
\hline \multirow{2}{*}{ Parameters } & \multicolumn{2}{c|}{ Black soils } & \multicolumn{2}{c|}{ Red soils } \\
\cline { 2 - 5 } & Range & Mean & \multicolumn{1}{c|}{ Range } & \multicolumn{1}{c|}{ Mean } \\
\hline $\mathrm{pH}$ & $7.2-8.7$ & 8.02 & $6.22-8.11$ & 7.53 \\
\hline $\mathrm{EC}(\mathrm{dsm}-1)$ & $0.11-0.70$ & 0.27 & $0.13-0.84$ & 0.34 \\
\hline $\mathrm{OC}(\mathrm{g} \mathrm{kg}-1)$ & $3.1-5.6$ & 4.40 & $3.6-5.3$ & 4.16 \\
\hline $\mathrm{N}(\mathrm{kg} \mathrm{ha}-1)$ & $156-236$ & 203.34 & $135-207$ & 180.64 \\
\hline $\mathrm{P}_{2} \mathrm{O}_{5}(\mathrm{~kg} \mathrm{ha}-1)$ & $22-34$ & 28.10 & $10-31$ & 23.53 \\
\hline $\mathrm{K}_{2} \mathrm{O}(\mathrm{kg} \mathrm{ha}-1)$ & $236-415$ & 332.30 & $130-402$ & 280.53 \\
\hline $\mathrm{Ca}(\mathrm{cmol} \mathrm{p}+\mathrm{kg}-1)$ & $15.30-38.10$ & 28.68 & $8.10-36.10$ & 25.66 \\
\hline $\mathrm{Mg}(\mathrm{cmol} \mathrm{p}+\mathrm{kg}-1)$ & $6.80-26.20$ & 16.46 & $6.30-21.30$ & 13.30 \\
\hline $\mathrm{S}(\mathrm{mg}$ kg-1 $)$ & $6.90-11.60$ & 8.66 & $6.30-1.10$ & 9.16 \\
\hline
\end{tabular}

Table.3 Micronutrient status in Nicchapura-2 watershed

\begin{tabular}{|c|c|c|c|c|}
\hline \multirow{2}{*}{$\begin{array}{c}\text { Parameters } \\
\left(\mathbf{m g ~ k g}^{-1}\right)\end{array}$} & \multicolumn{2}{|c|}{ Black soils } & \multicolumn{2}{c|}{ Red soils } \\
\cline { 2 - 5 } & Range & Mean & Range & Mean \\
\hline Iron & $0.58-5.92$ & 2.51 & $1.40-15.20$ & 7.51 \\
\hline Manganese & $0.60-10.83$ & 5.11 & $4.30-19.60$ & 10.90 \\
\hline copper & $0.01-0.41$ & 0.19 & $0.12-0.84$ & 0.43 \\
\hline Zinc & $0.06-4.81$ & 1.96 & $0.01-5.12$ & 3.25 \\
\hline
\end{tabular}

In Red soils exchangeable calcium and magnesium content ranged from 8.1 to 36.1 cmol $\left(\mathrm{p}^{+}\right) \mathrm{kg}^{-1}$ and 6.3 to $21.3 \mathrm{cmol}\left(\mathrm{p}^{+}\right) \mathrm{kg}^{-1}$ was recorded low calcium and magnesium, which might be due to the type of clay as well as due to its accelerated leaching and low organic carbon content. The exchangeable $\mathrm{Ca}$ and $\mathrm{Mg}$ content are attributed to the type and amount of clay present in these soils. High values of $\mathrm{CEC}$ and exchangeable $\mathrm{Ca}$ and $\mathrm{Mg}$ are an indication of dominance of smectite type of clay mineral as reported by Nandi and Dasog
(1992). The $\mathrm{Mg}$ content was present in low amount than $\mathrm{Ca}$ because of its higher mobility. These results are in conformity with findings of Sharma and Gangwar (1997).

The available sulphur status ranged from low to medium but majority of the area showed low in available sulphur content. In black soil, sulphur content ranged from 6.9 to $11.6 \mathrm{~kg} \mathrm{ha}^{-1}$ and in red soils ranged from 6.3 to $12.1 \mathrm{~kg} \mathrm{ha}^{-1}$. The low amount of available sulphur at surface soil samples were mainly because of the acidic 
reaction low EC and $\mathrm{OC}$ values in these mixture of both black and red soils (Ashok, 2001 and Madhan Mohan et al., 2008). On area basis about 577 ha of the study area was low and 53 ha were medium in available sulphur (Table 2 and Fig. 3).

\section{Micronutrient status in soils}

The available iron content in micro-watershed ranged from 0.58 to $15.2 \mathrm{mg} \mathrm{kg}^{-1}$. The available iron content in the black soils ranged from 0.58 to $5.92 \mathrm{mg} \mathrm{kg}^{-1}$ with the mean of $2.51 \mathrm{mg} \mathrm{kg}^{-1}$ whereas, in red soils it ranged from 1.4 to 15.2 $\mathrm{mg} \mathrm{kg}^{-1}$ with the mean of $7.51 \mathrm{mg} \mathrm{kg}^{-1}$. About 458 ha $(72.71 \%)$ of the study area deficient while 171 ha (27.28 percent) had sufficient in available iron status of study area. The available iron content was higher in red soil than black soil of the study area (Table 3). This may be due to the granite gneiss parent material which is known to possess higher iron content. The low availability of iron in black soils (Rajkumar, 1994) was attributed to its precipitation by $\mathrm{CaCo}_{3}$ and decreases the availability. About 458 ha $(72.71 \%)$ of the study area deficient while 171 ha (27.28 percent) had sufficient in available iron status of study area (Fig. 3).

The available manganese content in microwatershed ranged from 0.60 to $19.6 \mathrm{mg} \mathrm{kg}^{-1}$ and was higher in red soils than black soils but sufficient in both soils (Table 3 and Figure 3). The higher available manganese content in red soils attributed to its higher content in granite genesis parent material. Rajkumar et al., (1994) relatively lower available manganese content in black soils coupled with semi-arid conditions resulting in conversions of $\mathrm{Mn}^{2+}$ to $\mathrm{Mn}^{3+}$ form. Srikanth et al., (2008) reported that higher available manganese content in soils originated from granite genesis parent material with semiarid climate. The available zinc content of micro watershed area ranged from 0.01 to 0.84 $\mathrm{mg} \mathrm{kg}{ }^{-1}$. The available zinc was higher in red soils $\left(0.12\right.$ to $\left.1.0 .41 \mathrm{mg} \mathrm{kg}^{-1}\right)$ than black soils ( 0.12 to $\left.0.84 \mathrm{mg} \mathrm{kg}^{-1}\right)$. The larger extent of zinc deficiency was attributed to the alkaline soil condition and richness of $\mathrm{CaCO}_{3}$. Which might due to high precipitation of zinc as hydroxide and carbonates (Table 3 and Fig. 3). Many researchers reported reduced solubility of majority of zinc and there by decreased availability of zinc under alkaline soil conditions. An area of 613 ha was deficient in zinc accounting for 97.24 per cent of total geographical area (TGA) and 17 ha $(2.75 \%$ of TGA) was sufficient. The available copper content ranged from 0.06 to $4.81 \mathrm{mg} \mathrm{kg}^{-1}$ in black soils and 0.01 to $5.12 \mathrm{mg} \mathrm{kg}^{-1}$ in red soils was found to be sufficient in the micro watershed area. However mean available copper content was low in black soils $\left(1.96 \mathrm{mg} \mathrm{kg}^{-1}\right)$ than red soils (3.25 $\mathrm{mg} \mathrm{kg}^{-1}$ ). Lower copper content in black soil compared to red soil might be due to higher $\mathrm{pH}$ (Table 3 and Fig. 3), $\mathrm{CaCO}_{3}$ and clay content resulting in copper fixation. The overall higher copper content in the micro watershed area was due to the parent material (Rajkumar et al., (1994).

Soil $\mathrm{pH}$ ranged from neutral to alkaline in reaction (6.8 to 8.7), the $\mathrm{pH}$ of black soils was higher than red soils. Salt content was very low indicates soils are non-saline in nature and organic carbon content was low (3.1 to $5.6 \mathrm{mg}$ $\mathrm{kg}^{-1}$ ), Available nitrogen low (range 156 to 236 $\mathrm{kg} \mathrm{ha}^{-1}$ ). It might be due to low in organic carbon content and is mainly correlated with organic carbon. Available phosphorus content were low to medium (22 to $34 \mathrm{~kg} \mathrm{ha}^{-1}$ ), the black soils are shows high phosphorus than red soils. These variations of phosphorus in soils are may be due to variation soil properties like clay content, CEC and P fixation capacity. The exchangeable $\mathrm{Ca}$ and $\mathrm{Mg}$ content were sufficient and low in available sulphur content may be due to acidic reaction, low EC and OC values in both black and red soils. Available micronutrients such as zinc and iron are deficient but copper and manganese were sufficient in these soils of micro-watershed

\section{References}

Ashok, L.B., 2001. Sulphur status of selected soil series of Karnataka and studies on direct 
and residual effect of graded level of sulphur on crop. Ph.D. Thesis. Univ. Agric. Sci., Bangalore, Karnataka

Black, C.A., 1965. Methods of soil Analysis, Part I and II. American Society of Agronomy, Inc, Madison, Wisconsin, USA.

Dasog, G.S., and Patil, P. L., 2011. Genesis and classification of black, red and lateritic soils of Karnataka. In: Soil Science Research in North Karnataka, Dharwad chapter of ISSS (Ed.), $76^{\text {th }}$ annual convention of ISSS, p. 110.

Jackson, M. L., 1973. Soil Chemical Analysis. Prentice Hall of India (Pvt.) Ltd., New Delhi.

Lindsay, W.L., and Norvell, W.A., 1978. Development of DTPA soil test for zinc, iron, manganese and copper, Soil Science Society of American Journal, 42,421-428.

Madhan Mohan, M., 2008. Characterization and classification of soils and land suitability of a micro-watershed in Hangal taluk. M. Sc. (Agri) Thesis, Univ.Agric. Sci., Dharwad, Karnataka (India).

Nandi, S., and Dasog, G.S., 1992. Properties, origin and distribution of carbonate nodules in some Vertisols. J. Indian Soc. Soil Sci., 40: 329-334.

Patil, S.S., Patil V.C and AL-Gaddi K.A., 2011. Spatial variability in fertility status of surface soils. World appl. sci. J., 14(7): 1020-1024. Pedologie, 35: 133-136.

Pulakeshi, H. B., P., Patil, P. L. and Dasog, G. S., 2014. Characterization and classification of soil recourses derived from chlorite schist in northern transition zone of Karnataka. Karnataka J. Agric. Sci., 27(1): 14-21.

Rajkumar, G.R., 1994, Studies on forms and distribution of micronutrients in paddy soils of Tungabhadra project area, Karnataka. $M$. Sc. (Agri.) Thesis Univ. Agric. Sci., Dharwad

Rao, A.P.V.P., Naidu, M.V.S, Ramavatharam N. and Rao, G.R., 2008. Characterization, classification and evaluation of soils on different landforms in Ramachandrapuram mandal and Chittoor district in Andhra Pradesh and sustainable land use planning. J. Indian Soc. Soil Sci., 56(1): 23-33.

Ravikumar, M. A., 2004. Soil resource characterization of 48A distributary of Malaprabha right bank command for sustainable land use planning. M. Sc. (Agri.) Thesis, Univ. Agric. Sci., Dharwad, Karnataka.

Sharma, Y. K., and Gangwar, G. S., 1997. Distribution of different forms of sulphur and their relationship with some soil properties in Alfisols, Inceptisols and Mollisols of Moradabad District, Uttar Pradesh. J. Indian Soc. Soil Sci., 45:332335.

Shivaprasad, C. R., Reddy, R. S., Seghal, J. and Velayutaam, M., 1998. Soils of Karnataka for optimizing land use. NBPS \& LUP, Nagpur, 47 p. 15.

Sireesha, P.V.G., and Naidu, M. V. S., 2013. Studies on genesis, characterization and classification of soils in semi-arid agroecological region: A case study in Banaganapalle mandal of Kurnool district in Andra Pradesh. J. Indian Soc. Soil sci., 61(3): 161-178.

Srikanth, K.S., Patil. P. L., Dasog, G.S and Gali, S.K., 2008. Maping of available major nutrients of a micro-watershed in Northern dry Zone of Karnataka. Karnataka J. Agric. Sci., 21(3): 391-395.

Subbaiah, B.U., and Asija, G.L., 1956. Rapid procedure for the estimation of the available nitrogen in soil. Curr. Sci., 25:259-260.

Walkley, A.J., and Black, C.A., 1934. Estimation of soil organic carbon by the chromic acid titration method. Soil Sci., 37: 29-38.

\section{How to cite this article:}

Krishna, N.R., P. Chandravamshi and Ashok, L.B. 2017. Soil Fertility Status of Major Nutrients, Micronutrients and Mapping in Nicchapura-2 Micro Watershed of Davanagere District, Karnataka, India. Int.J.Curr.Microbiol.App.Sci. 6(9): 1178-1186. doi: https://doi.org/10.20546/ijcmas.2017.609.142 